\title{
Pilobolus species found on herbivore dung from the São Paulo Zoological Park, Brazil
}

\begin{abstract}
Aírton Viriato ${ }^{1}$
Received: May 2, 2007. Accepted: September 4, 2007

RESUMO - (Espécies de Pilobolus encontradas em fezes de herbívoros do Parque Zoológico de São Paulo, Brasil). Para o estudo de espécies de Pilobolus, foram coletadas 168 amostras de fezes de animais herbívoros no Parque Zoológico da cidade de São Paulo. Dez espécies foram verificadas, ilustradas e descritas e uma chave de identificação é apresentada.
\end{abstract}

Palavras-chave: fungos coprófilos, Mucorales, Zygomycota

ABSTRACT - (Pilobolus species found on herbivore dung from the São Paulo Zoological Park, Brazil). A study of Pilobolus species from 168 dung samples of various herbivoresous animals,- collected in the São Paulo Zoological Park, was carried out. Ten species were found, illustrated, described, and a key for their identification is provided.

Key words: coprophilous fungi, Mucorales, Zygomycota

\section{Introduction}

Pilobolus is a saprotrophic genus belonging to the Mucorales (Zygomycota), frequently found in herbivorous animals feces (Alexopoulos et al. 1996). The genus is characterized by coprophilous habit, positive phototropism and method of spore dispersal. In the dispersal process, the mature sporangium is thrown more than 2 meters by dehiscence of the mucilage found at the junction of the columella-with the sporangium, caused by the rupture of the subsporangial vesicle. This is why it is called "sporegun" dispersal (Ingold 1971). The group was studied and its taxonomy revised by Grove (1934). Since then there have been few works on the taxonomy of the group (Nand \& Mehrotra 1968; Tandon 1968; Zycha et al. 1969). In Brazil, Pilobolus species have been recorded by Trufem (1984), Viriato \& Trufem (1985) and Richardson (2001). The species of Pilobolus are attached to the substrate by an absorptive structure, the swollen trophocyst, semi-immersed in the substrate at the base of the sporangiophore. Generally the trophocysts are ovoid to globose, with a longcylindrical, rhizoidal extension. The sporangiophores are straight, never branched, positively phototropic, with two rings of orange pigment, one at the base and the other at the base of the subsporangial vesicle. The orange carotenoid pigments act as light sensors which are lined up with each other by the expanded subsporangial vesicle acting as a lens, so that the sporangium is always aimed at the brightest light. The sporangia are black, sub-hemispherical and have resistant walls. The columellae are generally smooth and long-elliptical, and sometimes mammiform. The spores are spherical to ellipsoid, and generally smooth walled, hyaline or with carotenoid pigments. The diagnostic structure of the Zygomycota is the zygosporangium, containing the zygospore, formed by the conjugation and fusion of two gametangia. No zygospores were observed during the study. The objective of this research is to contribute to the knowledge of the biodiversity of this group of fungi and to learn about their distribution on herbivorous dung from different species of mammals.

\section{Material and methods}

One hundred and sixty-eight samples of animal feces [camel (Camelus bactrianus L.), horse (Equus caballus L.), "cotia" (Dasyprocta fuliginosa L.), "guanaco" (Lama guanacoe Muller), "orix” (Orix gazela

\footnotetext{
1 Hospital Infantil Cândido Fontoura, Secretaria de Estado da Saúde, Rua Siqueira Bueno 1757, 03173-010 São Paulo, SP, Brasil (airtonviritaro@saude.sp.gov.br)
} 
L.), "veado-catingueiro" (Mazama gouazoubira Fischer), "veado-nobre" (Cervus elaphus L.), zebra (Equus burchelli Gray)] were collected monthly (from September 1994 to July 1995) from the Fundação Parque Zoológico de São Paulo by the breeder in the morning, using wooden spatulas, being careful to keep the samples intact. The samples were incubated in moist chambers, sterilized Petri-dishes, in a laboratory with ambient light and temperature conditions, for four or five days, when the observations were made. The morphology of each Pilobolus species was studied, measured with an eyepiece micrometer coupled to the optical microscope, and drawn with a drawing attachment/camera lucida. As Pilobolus specimens do not develop well in culture, they were removed end immediately examined.

\section{Results}

The following key is for the species we observed.

Key for the identification of Pilobolus species

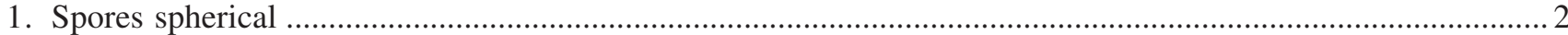

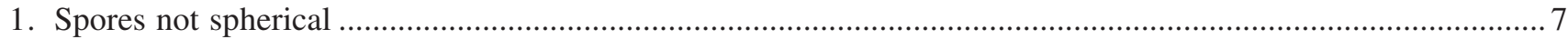

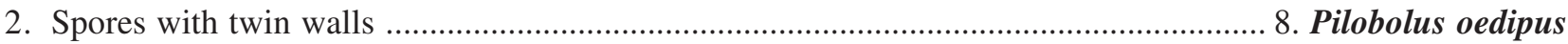

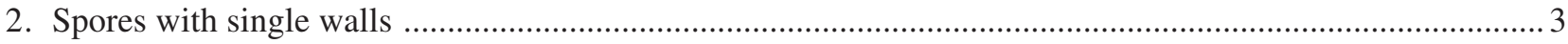

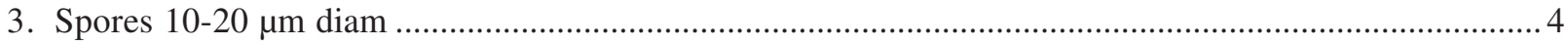

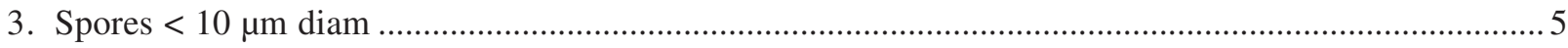

4. Sporangiophores $0.4-0.5 \mathrm{~mm}$ high ……….............................................................. 1. P. borzianus

4. Sporangiophores 4-6 mm high ...................................................................... 10. P. sphaerosporus

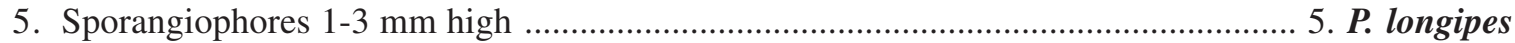

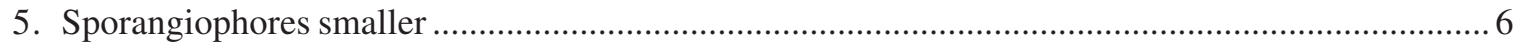





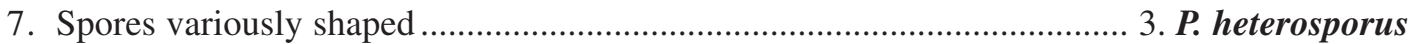

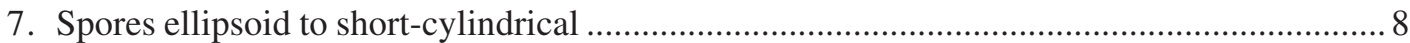

8. Sporangiophores $0.8-0.95 \mathrm{~mm}$ high; spores hyaline, short elliptical ............. 9. P. pullus

8. Sporangiophores $>1.5 \mathrm{~mm}$ high; spores yellow, elliptical to short cylindrical ............... 9

9. Columellae conical; trophocysts 500-700 $\mu \mathrm{m}$ long ................................... 4. P. kleinii

9. Columellae mammiform; trophocysts $350-400 \mu \mathrm{m}$ long ................... 2. P. crystallinus

1. Pilobolus borzianus Morini, Mem. Accad. Sci Inst. Bolgna ser. 6, 3: 126. 1906.

Fig. 1-8

Trophocysts ovoid to globose, 250-300x 150-250 $\mu \mathrm{m}$; rhizoidal extensions up to $150 \mu \mathrm{m}$, little orange pigmentation; sporangiophores long-cylindrical, 400-500×90-110 $\mu \mathrm{m}$; sporangia black, globose, 250-290×180-200 $\mu \mathrm{m}$; columellae smooth, long-elliptical, 130-150×100-120 $\mu \mathrm{m}$; subsporangial vesicles smooth, ovoid, 270-370 $\times 200-250 \mu \mathrm{m}$; spores smooth, yellow, with grainy contents, spherical, 10-20 $\mu \mathrm{m}$ diam. Collected from dung of horse (Oct., Nov., 1994, Jan., May, 1995), "guanaco" (Sep., 1994), "orix" (Sep., Dec.,1994, June, July, 1995), "veado-catingueiro" (October/1994), "veado-nobre" (February/1995, June/1995, July/1995), zebra (October/1994, May/1995). The observed material corresponds well with to the descriptions of Grove (1958), Naumov (1939) and Nand and Mehrota (1968). Pilobolus borzianus was recorded in the State state of São Paulo by Viriato and Trufem (1985) and the current material corresponds well with to their description. P. borzianus differs from the other species of the genus with spherical spores because of the spore size, which can reach $20 \mu \mathrm{m}$ diam. As regards to the sporangiophore height, only P. morinii approaches that of $P$. borzianus, but its spores are much smaller (up to $7 \mu \mathrm{m}$ diam.), and its columellae are semi elliptical, while those of $P$. borzianus are long-elliptical.

2. Pilobolus crystallinus (Wiggers) Tode, Schriften Naturforschenden Froukleich Berlin 5: 96. 1784.

Fig. 9-15

Trophocysts ovoid to globose, $350-400 \times 250-300 \mu \mathrm{m}$, with rhizoidal extensions up to $400 \mu \mathrm{m}$ long, little orange 
pigmentation; sporangiophores long cylindrical, 1.5-5.0 $\mathrm{mm} \times 115-150 \mu \mathrm{m}$, black sporangia, hemispherical to ovoid, $250-350 \times 240-340 \mu \mathrm{m}$, resistant and smooth walled; smooth columellae, mammiform, 180-200x $160-175 \mu \mathrm{m}$, subsporangial vesicles with smooth walls, without pigmentation, ovoid to globose 500-700x 400-600 $\mu \mathrm{m}$, yellow spores, homogeneous content, smooth, short-cylindrical, 8.0-10×7.0-9.0 $\mu \mathrm{m}$. Collected from dung of horse (December/1994, June/1995), "guanaco" (October/1994), "orix" (December/1994), "veado-catingueiro" (November, December/1994, May/1995), zebra (September/1994, October/1994, December/1994, January/1995, April/1995). The characteristics of the material well with the descriptions of Naumov (1939), Boedjin (1958), Grove (1958), Tandon (1968), and Richardson \& Watling (1969). Pilobolus crystallinus was also mentioned by Viriato and Trufem (1985) in the of São Paulo. It differs from the other species of the genus due to the short-cylindrical spores, up to $10 \mu \mathrm{m}$ long. The only species with similar characteristics is Pilobolus pullus, but it differs in sporangiophore height, because $P$. crystallinus is about $1,0 \mathrm{~mm}$ larger. $P$. pullus spores are short-elliptical and can reach up to $12 \mu \mathrm{m}$ long, bigger than in $P$. crystallinus.

2. Pilobolus heterosporus Palla, Zur Kenntniss der Pilobolus Arten, Österreichische Botanische Zeitschrift 50: 349. 1900.

Fig. 16-22

Trophocysts ovoid to globose, short-ellipsoid, $300-400 \times 250-300 \mu \mathrm{m}$, with rhizoidal extensions up to $150 \mu \mathrm{m}$ long, little yellow pigmentation; sporangiophores long-cylindrical, 2.0-3.0 $\mathrm{mm} \times 100-120 \mu \mathrm{m}$, black sporangia, hemispherical and ovoid, 350-400x 250-350 $\mu \mathrm{m}$, resistant wall; conical columellae, $140-150 \times 120-135 \mu \mathrm{m}$, little pigmented subsporangial vesicles, ovoid and ellipsoid, 450-550×350-400 $\mu \mathrm{m}$; smooth spores, soft yellowish grainy pigmentation, globose, oval, piriform to irregular, (8.5)10.0$18.0(20.0) \times(5.0) 7.0-9.0(11.0) \mu \mathrm{m}$. Collected from zebra's dung (October/1994). The observed material shows similarities with the descriptions of Naumov (1939), Grove (1958), Tandon (1968), and Nand \& Mehrotra (1968). Pilobolus heterosporus was cited by Viriato \& Trufem (1985) in the State of São Paulo. The referred taxon differs from the other species of the genus due to its irregular spores with grainy contents.

4. Pilobolus kleinii van Tieghem, Trois. Mém. Annales des Sciences Naturalles, ser 6. 4: 337-338. 1876.

Fig. 23-29

Trophocysts ovoid to globose, with yellow pigments, globose to elliptical, $550-700 \times 300-450 \mu \mathrm{m}$, with rhizoidal extensions up to $250 \mu \mathrm{m}$; sporangiophores long-cylindrical 3.0-5.0 $\mathrm{mm} \times 100-135 \mu \mathrm{m}$; black sporangium, hemispherical to lowered, 350-400x 150-300 $\mu \mathrm{m}$ diam., smooth and resistant wall, smooth columellae, conical, 200-205×150-190 $\mu$ m; smooth subsporangial vesicles, hyaline, ovoid to subellipsoid, 500-700 $\times 450-550 \mu \mathrm{m}$; yellow spores, refringent and with slightly grainy contents, smooth, ellipsoid, 11-9.0× 8.0-5.0 $\mu \mathrm{m}$. Collected from dung of camel (April/1995), horse (November/1994, February/1995, March/1995, May/1995), and zebra (September/1994, January/1995, February/1995, March/1995, June/1995). The characters of the are similar to the descriptions of Nand and Mehrotra (1968), Richardson and Watling (1969), and Liu and Yang (1973). For the state of São Paulo, the species was described and illustrated by Trufem (1984) and Viriato and Trufem (1985), and both descriptions correspond to the current material.

5. Pilobolus longipes van Tieghem, Trois. Mém. Annales des Sciences Naturalles, ser. 6. 4: 338-340. 1876.

Fig. 30-36

Trophocysts ovoid to globose, long-cylindrical, 400-750 $\times 200-300 \mu \mathrm{m}$, with rhizoidal extensions up to $950 \mu \mathrm{m}$, with a soft yellow pigmentation; sporangiophores 1.0-3.0 $\mathrm{cm} \times 90-110 \mu \mathrm{m}$; black sporangium, globose, ovoid to slightly levelled, 300-350 $\times 250-200 \mu \mathrm{m}$, resistant wall, with up to $1.0 \mu \mathrm{m}$ high thorns, smooth, conical columellae, 155-170x $140-150 \mu \mathrm{m}$; subsporangial vesicles with smooth walls, little pigmentation, ovoid, $650-700 \times 500-600 \mu \mathrm{m}$; yellow spores, grainy content, smooth, spherical, 6.0-15 $\mu \mathrm{m}$ diam. Isolated from horse (July/1995), and zebra (February/1995, June/1995, August/1995). The characters of the are similar to the descriptions of Grove (1958), Nand \& Mehrotra (1968), and Tandon (1968). Spores of Pilobolus sphaerosporus and P. oedipus are almost the same size as those of $P$. longipes, but those of the former are lightly pigmented and reaches $14 \mu \mathrm{m}$ diam., while the latter has spores with twin walls, which was not seen in the material being discussed.

6. Pilobolus morinii Saccardo, Sylloge Fungorum 17: 505. 1905.

Fig. 37-43

Trophocysts ovoid to globose, with little yellowish pigmentation, spherical to ovoid, $250-300 \times 150-250 \mu \mathrm{m}$, rhizoidal extensions up to $150 \mu \mathrm{m}$; sporangiophore longcylindrical, 400-800 $\times 80-110 \mu \mathrm{m}$; black sporangium, smooth and resistant walls, globose to hemispherical, 150-200×100-150 $\mu \mathrm{m}$; columellae with smooth wall, hyaline, half-elliptic, 110-140×70-100 $\mu \mathrm{m}$; hyaline subsporangial vesicles, smooth wall, oval, $250-550 \times 200$ - 
$300 \mu \mathrm{m}$; yellow spores, smooth, little grainy content, globose, 5.0-7.0 $\mu \mathrm{m}$ diam. Isolated from zebra (September/1994). The observed material corresponds to that described by Naumov (1939). The descriptions provided by Boedjin (1958) and Tandon (1968) differ in sporangiophore height, mentioned as up to $3.0 \mathrm{~mm}$. The taxon differs from the other species of the genus, with spherical spores, because of spore size that can reach $7.0 \mu \mathrm{m}$ diam., and also due to the half-elliptical columella form which is seen only in this species.


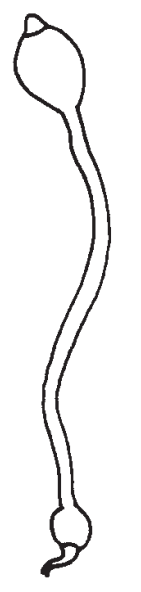

20

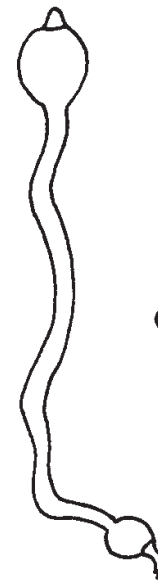

21

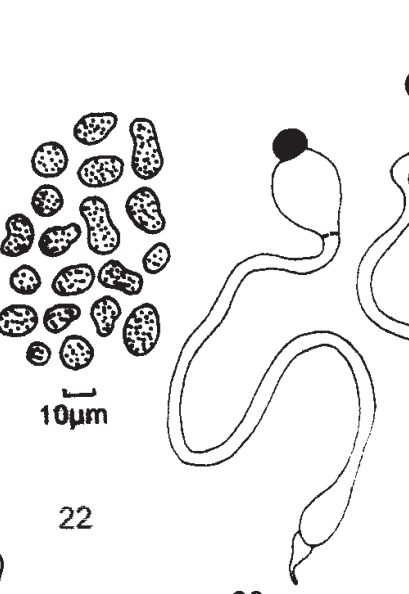

23

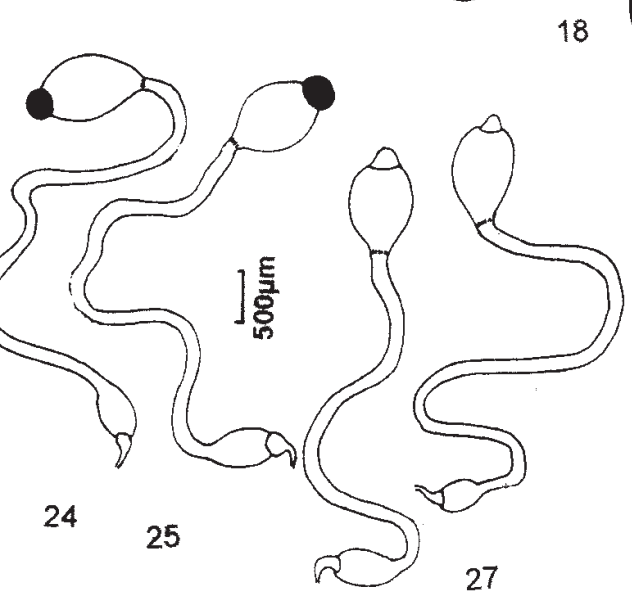

26
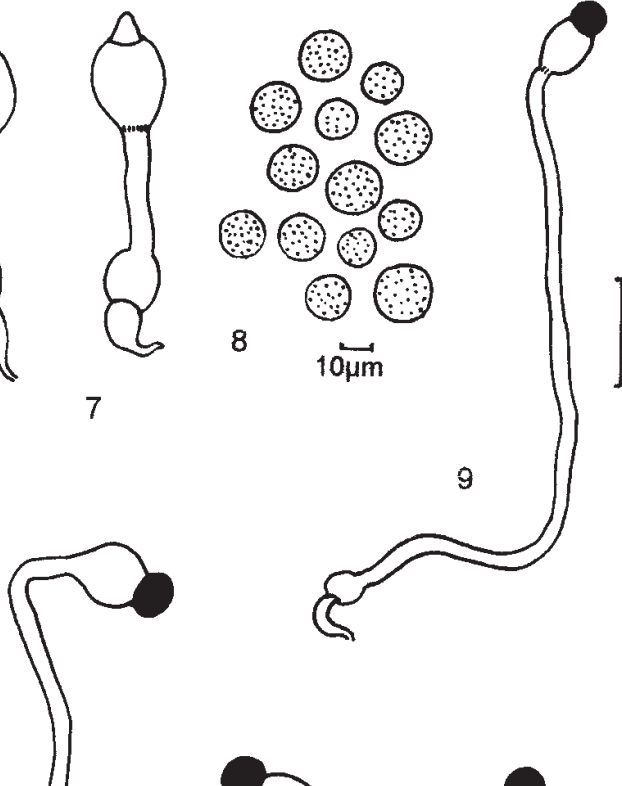

10


16
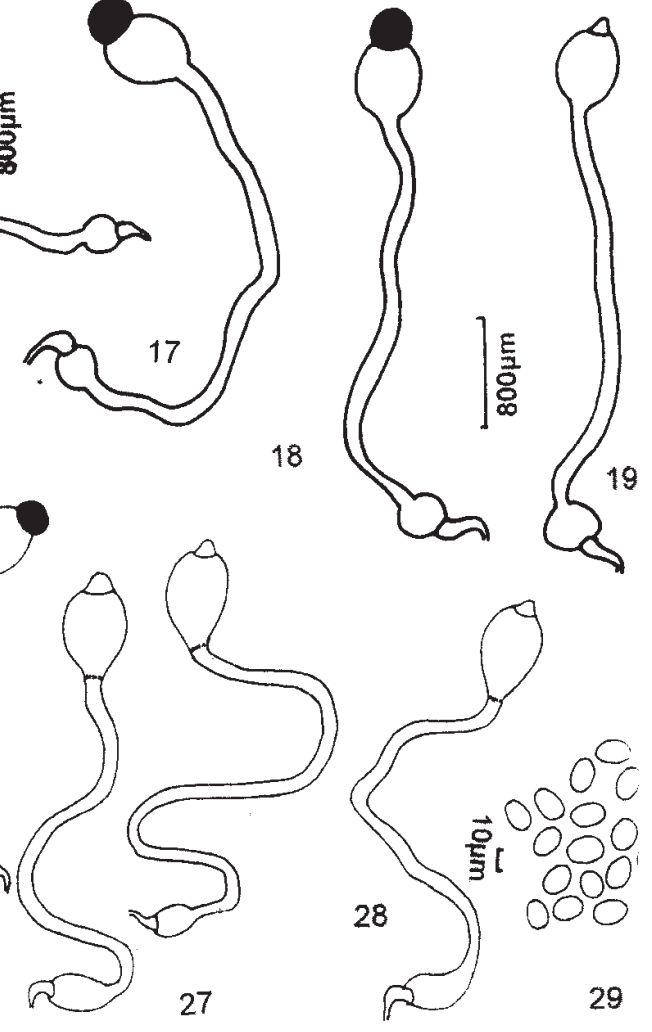

29

Figures 1-8. Pilobolus borzianus Morini: 1-3. Sporangiophores. 4-7. Columellae. 8. Spores. Figures 9-15. Pilobolus crystallinus (Wiggers) Tode: 9-11. Sporangiophores. 12-14. Columellae. 15. Spores. Figures 16-22. Pilobolus heterosporus Palla: 16-18. Sporangiophores. 19-21. Columellae. 22. Spores. Figures 23-29. Pilobolus kleinii van Tieghem: 23-25. Sporangiophores. 26-28. Columellae. 29. Spores. 

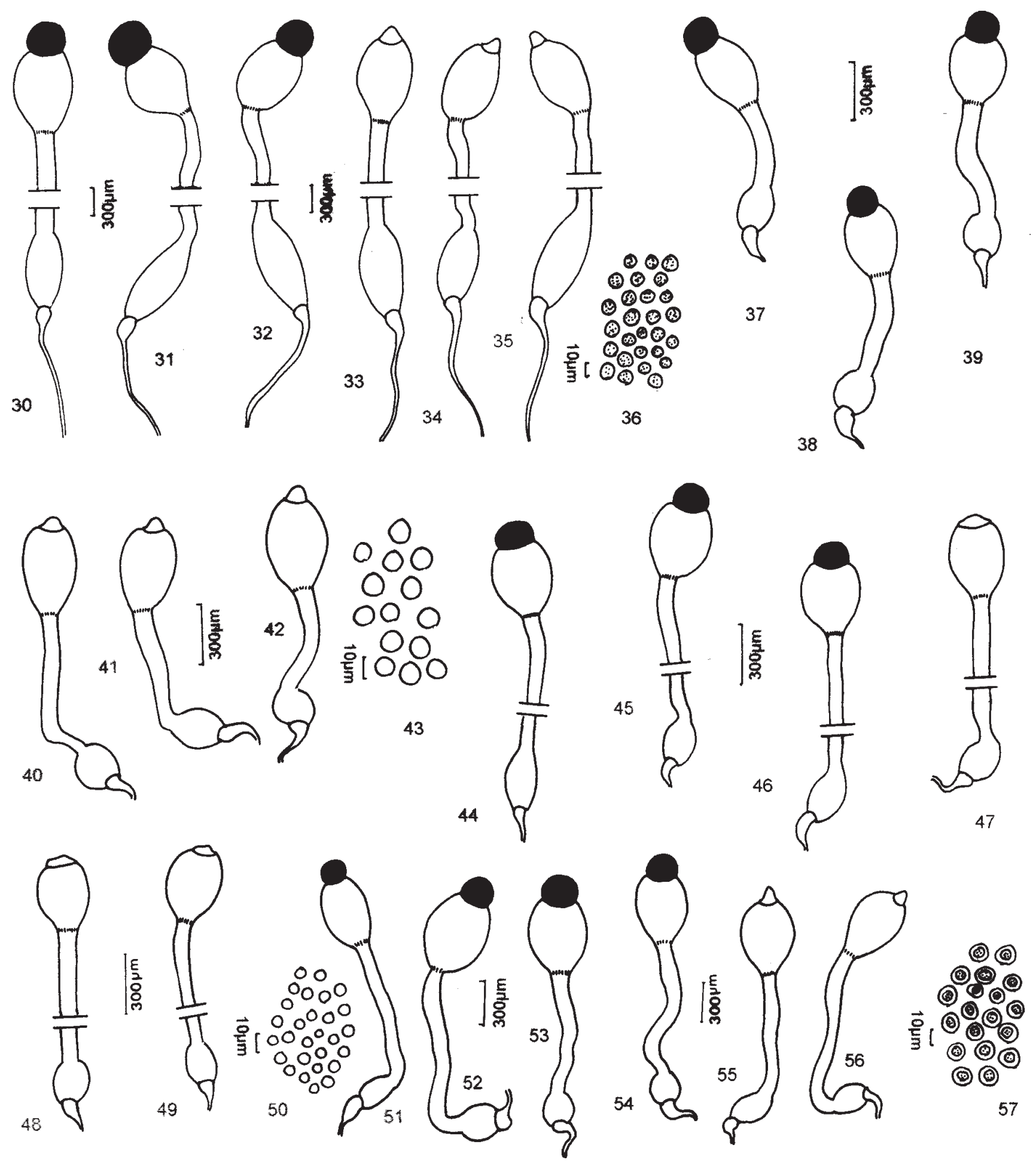

Figures 30-36. Pilobolus longipes van Tieghem: 30-32. sporangiophores. 33-35. Columellae. 36. Spores. Figures 37-43. Pilobolus morinii Saccardo: 37-39. Sporangiophores. 40-42. Columellae. 43. Spores. Figures 44-50. Pilobolus nanus van Tieghem: 44-46. Sporangiophores. 47-49. Columellae. 50. Spores. Figures 51-57. Pilobolus oedipus Montagne: 51-54. Sporangiophores. 55-56. Columellae. 57. Spores. 
7. Pilobolus nanus van Tieghem, Trois. Mém. In Annales des Sciences Naturalles, ser 6 4: 340-342. 1876.

Fig. 44-50

Trophocysts ovoid to globose, elliptical, 200-250x 155-195 $\mu \mathrm{m}$, with rhizoidal extension up to $120 \mu \mathrm{m}$, little yellowish pigmentation; sporangiophores longcylindrical, $0.5-1.0 \mathrm{~mm} \times 55-65 \mu \mathrm{m}$; black sporangia, resistant wall, hemispherical to ovoid, 170-200x 130-150 $\mu \mathrm{m}$; columellae with smooth walls, convex, $75-95 \times 120-140 \mu \mathrm{m}$; subsporangial vesicles with smooth wall, hyaline, little pigmentation, slightly ovoid, 290-310×270-290 $\mu \mathrm{m}$; hyaline spores, smooth, globose, 3.5-4.0 $\mu \mathrm{m}$ diam. Collected from dung of horse (October/1994). The isolated material corresponds well with the description of Grove (1958), except for columella format. There have been no previous reports from Brazil. P. nanus differs from the other species of the genus with spherical spores because its spores are smaller, up to $5.5 \mu \mathrm{m}$ diam. Additionally, it has convex columellae, which do not occur in any other species of the genus.

8. Pilobolus oedipus Montagne, Ann. Soc. Linn. de Lyon p. 1-7. 1828.

Fig. 51-57

Trophocysts ovoid to globose, globose to subglobose, 200-250×145-190 $\mu \mathrm{m}$, with rhizoidal extension up to $300 \mu \mathrm{m}$, little yellowish pigmentation; sporangiophores long-cylindrical, 1.5-2.0 $\mathrm{mm} \times$ 100-110 $\mu$ m; black sporangia, wall with cuticle, resistant, spherical to hemispherical, $350-450 \times 240-300 \mu \mathrm{m}$; columellae smooth walled, $200-250 \times 130-150 \mu \mathrm{m}$; subsporangial vesicle smooth walled, little pigmentation, ovoid to elliptical, 550-650 $\times 450-500 \mu \mathrm{m}$; yellow spores, grainy content, smooth wall, twin, globose, 9.0-16 $\mu \mathrm{m}$ diam. Collected from dung of horse (January/1995), and zebra (November/1994, March/1995, June/1995). The observed material corresponds well to the description of Nand \& Mehrotra (1968). Pilobolus oedipus was registered in the state of São Paulo by Viriato \& Trufem (1985). It differs from the other species of the genus with spherical spores because of the specific twin wall of the spores.

9. Pilobolus pullus Massee, Kew Bulletin p. 160. 1901. Fig. 58-64

Trophocysts ovoid to globose, hyaline, globose to ovoid, 110-155×60-100 $\mu \mathrm{m}$, with rhizoidal extension up to $300 \mu \mathrm{m}$; isolated sporangiophores long-cylindrical, 800-950 $\times 80-100 \mu \mathrm{m}$; black sporangia, with resistant wall, hemispherical to lowered, 200-300×170-210 $\mu$; smooth columellae, mammiform, $150-200 \times 120-140 \mu$ m; subsporangial vesicle with smooth wall, no pigmentation, ovoid to globose, $550-650 \times 350-4500 \mu \mathrm{m}$; hyaline spores, smooth, short elliptical, 8.5-12×6.5-7.5 $\mu \mathrm{m}$. Isolated from dung of horse (November/1994) and "guanaco" (September/1994). The isolated material has characters that agree with the description of Naumov (1939). Pilobolus pullus was recorded in the state of São Paulo by Viriato \& Trufem (1985). It differs from the other species of the genus because it has short-elliptical spores, up to $12 \mu \mathrm{m}$. The columellae are typically mammiform. Pilobolus crystallinus is the only species whose characteristics come close to P. pullus, but the sporangiophores of $P$. crystallinus are larger, reaching $1.9 \mathrm{~mm}$ high.

10. Pilobolus sphaerosporus Palla, Oesterr. Bot. Zeitschr. 50: 400. 1900.

Fig. 65-71

Trophocysts ovoid to globose, long-ovoid, $550-700 \times 250-275 \mu \mathrm{m}$, with rhizoidal extension up to $600 \mu \mathrm{m}$, with little pigmentation; sporangiophores longcylindrical, 4.0-6.0 $\mathrm{mm} \times 130-150 \mu \mathrm{m}$; black sporangia, with resistant wall, hemispherical to ovoid, 185-270x 295-400 $\mu \mathrm{m}$; smooth columellae, mammiform, 95-200×65-150 $\mu \mathrm{m}$; subsporangial vesicles smooth walled, no pigmentation, ovoid to globose, $650-800 \times 625-695 \mu \mathrm{m}$; yellow spores, smooth, grainy content, globose, $10-20 \mu \mathrm{m}$ diam. Observed on dung of horse (October/1994, November/1994, March/1995, July/1995), "guanaco" (November/1994, December/1994, January/1995), and zebra (October/1994, December/1994). The studied material is similar to the descriptions of Naumov (1939), Grove (1958) and Nand \& Mehrotra (1968). Pilobolus sphaerosporus was isolated and described in the state of São Paulo by Viriato \& Trufem (1985). It differs from the other species of the genus due to sporangiophores height, up to 4-6 mm high.

\section{Acknowledgments}

We would like to thank to Dr. Mike J. Richardson, for suggestions; Dr. Faiçal Simon (in memorian) and Dr. Mario Borges da Rocha, for making possible the collection of the feces from the herbivorous mammals in the Parque Zoológico de São Paulo. 




58

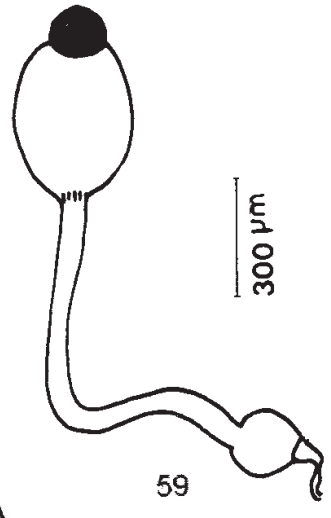

60
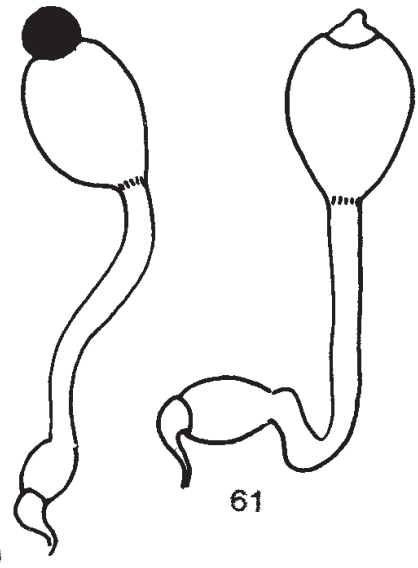

62

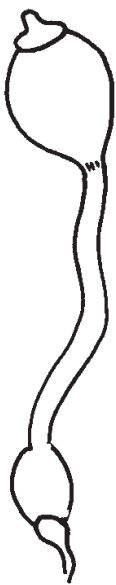



63

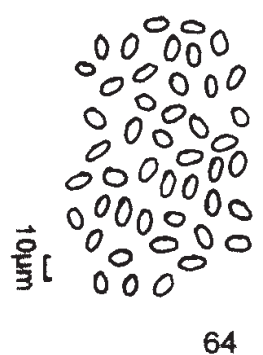

64
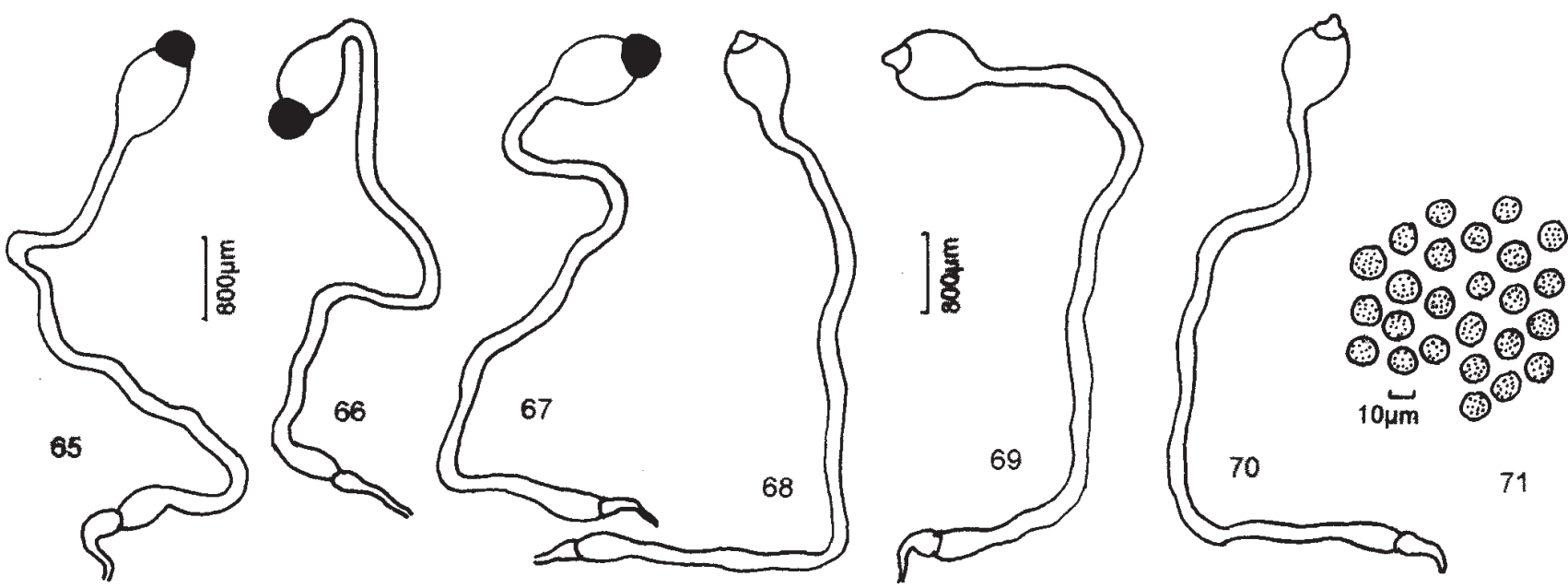

Figures 58-64. Pilobolus pullus Massee: 58-60. Sporangiophores. 61-63. Columellae. 64. Spores. Figures 65-71. Pilobolus sphaerosporus Palla: 65-67. Sporangiophores. 68-70. Columellae. 71. Spores.

\section{References}

Alexopoulos, C.J.; Mims, C.W. \& Blackwell, M. 1996. Introductory Mycology. 4 ed. EUA, John Wiley \& Sons.

Boedijn, K. B. 1958. Notes on the Mucorales of Indonesia. Sydowia, Annales Mycologicy 12: 321-362.

Grove, W.B. 1934. A systematic account and arrangement of the Pilobolidae. Pp.190-224. In: A.H.R. Buller. Researches on fungi. v.6. New York, Hafner Publishing.

Ingold, C.T. 1971. Fungal spores: their liberation and dispersal. London, Oxford University Press.

Liu, C. \& Yang, B. 1973. Studies on certain species of Taiwan Mucorales. Taiwania 18: 73-82.
Nand, K. \& Mehrotra, B.S. 1968. Species of Pilobolus and Pilaira from India. Sydowia, Annales Mycologici, ser. II. 22: 299-306.

Naumov, N.A. 1939. Cles des Mucorinées (Mucorales). Encyclopédie Mycologique 9: 1-137.

Richardson, M.J. \& Watling, R. 1969. Keys to fungi on dung. Bulletin of the British Mycological Society 3: $86-88$.

Richardson, M.J. 2001. Coprophilous Fungi from Brazil. Brazilian Archives of Biology and Technology 44: 283-289.

Tandon, R.N. 1968. Mucorales of India. New Delhi: Indian Council of Agricultural Research.

Trufem, S.F.B. 1984. Mucorales do Estado de São Paulo: 4. Espécies Coprófilas. Rickia 11: 53-64.

Viriato, A. \& Trufem, S.F.B. 1985a. Mucorales do Estado de São Paulo: 5. Pilobolaceae. Rickia 12: 77-88.

Zycha, H.; Siepmann, R. \& Linnemann, G. 1969. Mucorales Lehre: J. Cramer. 